\title{
The assessment of the relationship between the severity of gingivitis and the glycosylated hemoglobin levels in adolescent and adult patients with type 1 diabetes
}

Jakub Lipski', Dorota Burchardt², Anna Duda-Sobczak ${ }^{3}$, Marzena Wyganowska-Świątkowska ${ }^{1}$

${ }^{1}$ Department of Dental Surgery and Periodontology, Poznań University of Medical Sciences, Poland

2 Department of Pediatric Dentistry, Poznań University of Medical Sciences, Poland

${ }^{3}$ Department of Internal Medicine and Diabetology, Poznań University of Medical Sciences, Poland

Abstract

Background. Diabetes and periodontitis belong to the group of civilizational diseases, which are not associated with any specific bacterial or viral infection but with the rapid development of civilization and technological advances that affect comfort and quality of life. Civilizational diseases occur in highly developed and developing societies. Glycosylated hemoglobin A1c ( $\mathrm{HbA1c}$ ) is one of the standard indicators for the assessment of metabolic compensation in diabetes that reflects the risk of disease complications. One of the significant complications of diabetes that manifests in the oral cavity is gingival and periodontal inflammation, which is directly related to increased insulin resistance and worsened diabetes compensation. Factors influencing inflammation are the patient's age, directly linked with fine motor skills when it comes to cleaning teeth, and patients' awareness related to cause-and-effect relationship between dental hygiene, gingival and periodontal inflammation, and $\mathrm{HbA1c}$ testing during routine check-ups.

Objectives. To compare the relationship between gingival inflammation and metabolic compensation (HbA1c levels), depending on the patient's age.

Materials and methods. The study involved 100 patients (50 adolescents and 50 adults, 42 M; 58 F) with type 1 diabetes. The study group was divided according to sex and age into 19 male adolescent patients (10-18 years old; mean age $15.5)$ and 23 male adult patients (19-45 years old; mean age 27.1). The mean duration of diabetes was 7 years in the group of adolescents and 11 years in the group of adults. The HbA1c levels and gingival index (GI) were measured in all patients. The obtained results were statistically analyzed.

Results. By comparing the study groups, higher HbA1c values were reported in the group of adolescents. HbA1c has been shown to correlate with the GI in adolescents and adults. Despite poorer compensation for diabetes (higher HbA1c), GI values were similar in adolescents and adults.

Keywords

Type 1 diabetes $\cdot$ gingival inflammation glycosylated hemoglobin • disease of civilization

Received: 09.11.2020, Accepted: 15.07.2021

\section{Background}

Diabetes mellitus is a systemic metabolic disease caused by an absolute or relative insulin deficiency. The healing process in diabetes is impaired due to monocyte and macrophage dysfunction, chronically elevated levels of proinflammatory cytokines, and decreased expression of growth factors inhibiting cell proliferation and extracellular matrix synthesis [1, 2]. Increased fibroblast apoptosis with concomitant accumulation of advanced glycation end-products (AGEs) is another suggested mechanism of impaired healing in diabetes [3]. Glycated hemoglobin $\mathrm{HbA} 1 \mathrm{c}$ is considered the gold standard for assessing the compensation of diabetes [4]. HbA1c reflects the average glycemia over the last 3-4 months, with about $50 \%$ of the HbA1c formed in the month prior to sampling [5].

$\mathrm{HbA1c}$ has been shown to have a strong predictive power for chronic diabetic complications [1] including microand macroangiopathy [6]. Gingivitis and periodontitis have been considered clinical complications in diabetic patients, manifested by increased gingival crevicular bleeding, pocket probing depth, and the loss of connective tissue attachment $[7,8,9]$. At the same time, the course of diabetes is affected by many inflammatory mediators produced locally in the periodontal tissues and secreted into the bloodstream, such as interleukin- $\beta$ (IL- $\beta$ ) and tumor necrosis factor- $\alpha$ (TNF- $\alpha$ ). Tumor necrosis factor- $\alpha$ and IL-1 $\beta$ increase serine phosphorylation of insulin receptor substrate (IRS-1 and IRS- 
2) proteins on the surface of the insulin target cells [10]. This process leads to impaired signal transduction and weaker insulin action on cells [11], making cells less sensitive to insulin and reducing blood glucose uptake and tissue glucose storage. This leads to disturbed glucose metabolism and hyperglycemia, both having adverse effects on periodontal tissues [12]. Management of comorbid periodontal disease in patients with diabetes may significantly improve the compensation of diabetes [13]. There are still no conclusive data on the relationship between diabetes, gingivitis, and periodontitis. However, a close bidirectional relationship between these two disease entities has been found. There is a complex relationship between uncompensated diabetes and chronic inflammation in the periodontal tissues [14, 15].

\section{Objectives}

This study aimed to evaluate the association between the severity of gingivitis and $\mathrm{HbA} 1 \mathrm{c}$ levels in adolescents and adults with type 1 diabetes.

\section{Material and methods}

With the approval of the Bioethics Committee at Poznan University of Medical Sciences, we enrolled 100 patients with type 1 diabetes: 50 adolescents (19 males; mean age 15.5 years) and 50 adults (23 men; mean age 27.1 years). The mean duration of the disease was 7 and 11 years, respectively (Table 1). All study participants gave informed consent to participate in the study; however, in the case of adolescents, consent was given by legal guardians or by the patients themselves if they were over 16 . The study exclusion criteria were current orthodontic treatment and pregnancy. The gingival status of all patients was clinically examined according to the gingival index (GI) [16]. To objectify study results, all assessments were performed by a single physician. Gingival index was assessed at teeth 16, 11, 24, $36,31,44$, and in the case of unerupted or missing teeth
24 and/or 44, at teeth 26 and/or 46 . The assessment was performed according to a four-grade gingival status index: 0 - healthy gingiva, pale pink in color; 1 - mild inflammation, a slight color change and mild structural change of the gingival tissue, no bleeding on probing; 2 - moderate inflammation: redness, swelling, glossy and hypertrophic gingiva, bleeding on pressure or probing; 3 - severe inflammation: significant redness and swelling, ulceration, tendency to spontaneous bleeding $[9,17]$.

Fasting $\mathrm{HbA1c}$ was measured in all patients using standard laboratory methods [13, 18].

The results were statistically analyzed with STATISTICA v. 10.0. A p-value $<0.05$ was considered statistically significant. The correlation analysis was performed using Spearman's rank correlation coefficient (Rs). All variables were tested for a normal distribution using the Kolmogorov-Smirnov test with Lilliefors correction. Nonparametric tests were used for data analysis. Statistical analyses were performed using MannWhitney $U$ test and chi-square test. Results were presented as counts, means, and interquartile ranges (IQR).

\section{Results}

The study involved 50 adolescents (19 males) and 50 adults (23 males). In the whole study group, the mean age was 21.3 years, the level of $\mathrm{HbA} 1 \mathrm{c}$ was $9.9 \%$, and the gingival index (GI) was 0.79 (Table 2). The mean age of the adolescent patients was 15.5 years, and of the adult patients 27.1 years $(p=0.000001)$. Compared to the group of adults, adolescent patients had worse metabolic compensation expressed by higher $\mathrm{HbA} 1 \mathrm{c}(11.7 \%$ vs. $8.2 \% ; p=0.000001)$ and higher $\mathrm{GI}$ values ( 0.83 vs. $0.76 ; p=0.46$ ) (Table 3 ). These differences were sex-independent.

\section{Discussion}

It may be difficult to compare study results on diabetes metabolic compensation in relation to gingival and

Table 1. Characteristics of the studied groups

\begin{tabular}{|c|c|c|c|c|c|c|c|c|c|c|c|}
\hline $\begin{array}{l}\text { Adolescents } \\
\quad(n=50)\end{array}$ & Minimum & Maximum & Average & SD & IQR & $\begin{array}{l}\text { Adults } \\
(n=50)\end{array}$ & Minimum & Maximum & Average & SD & IQR \\
\hline Age & 10 & 18 & 15.5 & 3.7 & $12-16$ & Age & 19 & 45 & 27.1 & 7.7 & $21-32$ \\
\hline $\begin{array}{l}\text { Duration of dia- } \\
\text { betes [years] }\end{array}$ & 4 & 10 & 7 & 1.8 & $5-8$ & $\begin{array}{l}\text { Duration of dia- } \\
\text { betes [years] }\end{array}$ & 4 & 15 & 11 & 2.8 & $8-13$ \\
\hline $\operatorname{Sex}[f / m ; n]$ & $31 / 19$ & & & & & $\operatorname{Sex}[f / m ; n])$ & $27 / 23$ & & & & \\
\hline
\end{tabular}


Table 2. Total value of parameters in the study group

\begin{tabular}{cccccc}
\hline $\begin{array}{c}\text { Total } \\
\mathbf{n = 1 0 0}\end{array}$ & $\begin{array}{c}\text { Mini- } \\
\text { mum }\end{array}$ & $\begin{array}{c}\text { Maxi- } \\
\text { mum }\end{array}$ & $\begin{array}{c}\text { Aver- } \\
\text { age }\end{array}$ & SD & IQR \\
\hline Age & 10 & 45 & 21.3 & 8.2 & $16-25$ \\
$\begin{array}{c}\text { Duration of } \\
\text { diabetes [years] }\end{array}$ & 3 & 15 & 7 & 2.3 & $6-11$ \\
HbA1c [\%] & 5.6 & 15.2 & 9.9 & 2.4 & $7.8-12.0$ \\
GI & 0.07 & 1.67 & 0.79 & 0.46 & $0.43-1.03$ \\
sex [f/m; $\mathbf{n}]$ & $58 / 42$ & & & & \\
\hline
\end{tabular}

periodontal disease. This ambiguity of interpretation is often related to the small sample size and different indices to assess oral health status [19]. In our study, gingival health status was assessed with GI in a group of 100 patients with type 1 diabetes. We chose $G$ l because of its ease of use in the outpatient setting and because it helped exclude patients with symptoms of supportive tissue destruction. However, we reported gingivitis in $100 \%$ of the study participants, and $\mathrm{GI}$ values ranged from 0.2 to 2.8 . Therefore, our study group differs from other groups in terms of the sample size and the status of periodontal tissues. In a group of Brazilian children aged $13 \pm 3.5$ years, gingivitis was reported in $21 \%$ and periodontitis in $6 \%$ of the study participants [20, 21]. In a group of Lithuanian children aged 10-15 years with type 1 diabetes, gingivitis was recorded in $27 \%$ compared to $13 \%$ in nondiabetics [22]. It is also important to note that in these studies the mean $\mathrm{GI}$ values in children aged 5-9 years was $1.54 \pm 0.5$, and $1.14 \pm 0.5$ in the healthy control, whereas in children aged 10-14 years these indices were, respectively, $1.98 \pm 0.6$ and $1.17 \pm 0.5$ [5], so significantly higher than in the Polish population (mean 0.83 for adolescents vs. mean 0.76 for adults).
Current studies indicate that treatment of gingival and periodontal inflammation can improve $\mathrm{HbA} 1 \mathrm{c}$ values by $0.4 \%$ [2, 23]. In periodontitis, chronic infection of the oral tissues increases insulin resistance, which contributes to seemingly worse metabolic compensation for diabetes [24, 25]. The interaction of bacterial by-products with phagocytes and fibroblasts leads to chronic release of proinflammatory cytokines, including interleukin 1 beta (IL-1 $\beta$ ), interleukin 6 (IL-6), tumor necrosis factor (TNF- $\alpha$ ), prostaglandin E2 (PGE2), and acute phase C-reactive protein (CRP) [14, 26]. We observed a statistically significant correlation between $\mathrm{HbA} 1 \mathrm{c}$ levels and $\mathrm{GI}$ values (Table 4). Moreover, we reported a statistically significant correlation between age and metabolic control in patients with type 1 diabetes. Compared to adults, adolescent patients had worse metabolic control (mean HbA1c 11.7 vs. mean HbA1c 8.2; $\mathrm{p}=0.000001$, respectively). Younger patients were less aware of their disease as compared to adults who had been educated about diabetes over a longer period of time. The same trend was noted for oral hygiene [23, 27].

\section{Conclusions}

The higher mean $\mathrm{Gl}$ values observed in the group of adolescents ( 0.83 compared to 0.76 in adults) can be attributed to their hygienic habits. This may be due to the fact that adult patients have better manual skills, better techniques of oral hygiene, and more available oral hygiene tools [20]. In younger patients, the period of tooth replacement negatively affects $\mathrm{GI}$ and, consequently, gingival and periodontal inflammatory markers [28]. Studies show that the mixed dentition period is associated with higher gingival inflammation and thus with higher GI values [6, 29]. Gingivitis in patients with type 1 diabetes may be age-dependent, but is closely related to

Table 3. Comparison of children and adults in relation to the studied parameters

\begin{tabular}{|c|c|c|c|c|c|c|c|c|c|c|c|c|c|}
\hline $\begin{array}{l}\text { Adolescents } \\
\qquad(n=50)\end{array}$ & $\begin{array}{l}\text { Mini- } \\
\text { mum }\end{array}$ & $\begin{array}{l}\text { Maxi- } \\
\text { mum }\end{array}$ & Average & SD & IQR & $\begin{array}{l}\text { Adults } \\
(n=50)\end{array}$ & $\begin{array}{l}\text { Mini- } \\
\text { mum }\end{array}$ & $\begin{array}{l}\text { Maxi- } \\
\text { mum }\end{array}$ & Average & SD & IQR & $\begin{array}{l}\text { Adults vs. } \\
\text { adolescents }\end{array}$ & $\mathbf{p}$ \\
\hline Age & 10 & 18 & 15.5 & 3.7 & $12-16$ & age & 19 & 45 & 27.1 & 7.7 & 21-32 & 15.5 vs. 27.1 & 0.000001 \\
\hline $\begin{array}{c}\text { Duration } \\
\text { of diabetes } \\
\text { [years] }\end{array}$ & 4 & 10 & 7 & 1.8 & $5-8$ & $\begin{array}{c}\text { duration of } \\
\text { diabetes } \\
\text { [years] }\end{array}$ & 4 & 15 & 11 & 2.8 & $8-13$ & 7 vs. 11 & 0.00001 \\
\hline HbA1c [\%] & 9.6 & 15.2 & 11.7 & 1.7 & $\begin{array}{l}9.8- \\
12.9\end{array}$ & HBA1c [\%] & 5.6 & 14.4 & 8.2 & 1.7 & $7.2-8.7$ & 11.7 vs. 8.2 & 0.000001 \\
\hline GI & 0.07 & 1.67 & 0.83 & 0.6 & $\begin{array}{c}0.38- \\
1.15\end{array}$ & GI & 0.00 & 1.38 & 0.76 & 0.3 & $0.5-1.0$ & 0.83 vs. 0.76 & 0.46 \\
\hline
\end{tabular}


Table 4. Correlation between gingival index and $\mathrm{HbA} 1 \mathrm{c}$ levels in the study groups

\begin{tabular}{cccc}
\hline Correlated variables & $\begin{array}{c}\text { Study group } \\
\text { (total) }\end{array}$ & Adolescents & Adults \\
\hline HbA1c \& GI & $R s=0.24 ; p=0.0157$ & Rs $=0.29 ; p=0.039$ & $R s=0.50 ; p=0.0002$ \\
\hline
\end{tabular}

${ }^{*} p<0.05:$ the level of statistical significance.

metabolic compensation (expressed by HbA1c levels) [30, 31]. Regardless of age, patients with diabetes and coexisting gingival and periodontal disease should be informed and properly educated about the interaction between oral hygiene, periodontal status, and general health [32]. Treatment of gingivitis and periodontitis involves hygienization, correction, and maintenance [33]. The first two stages constitute an active treatment, and the third phase is to maintain treatment results [34]. Effective treatment of diabetes requires good cooperation between a diabetologist and a dentist, because of the bidirectional relationship between diabetes and periodontal disease [35]. Patients with undiagnosed diabetes who present to the dentist with diabetic symptoms should be referred to a specialist (diabetologist) for additional testing in order to establish a diagnosis and undertake appropriate treatment [36]. Early diagnosis of diabetes and good glycemic control positively affect the course of the underlying disease and the periodontal presentation [37]. Treatment of periodontal disease in diabetic patients may reduce the incidence of diabetic complications. Therefore, diabetologists should refer all patients without dental insurance to a dentist for diagnosis, prevention, and, if necessary, treatment of periodontal disease [38, 39].

\section{Authors' Contribution}

J.L.: Supervising the project, acquisition of data, data analysis and interpretation, writing (original draft preparation) review and editing, literature review, final proofreading and approval of the version for publication; D.B.: Acquisition of data, data analysis and interpretation; A.D.S.: Research concept and design, supervising the project, data analysis and interpretation; M.W.Ś.: Research concept and design, prevising the project, writing (original draft preparation), review and editing, literature review, final proofreading and approval of the version for publication.

\section{Conflict of Interest}

The authors have no potential conflicts of interest to declare.

\section{Ethics Approval}

Due to the nature of the research, the consent of the ethics committee was not required.

\section{References}

[1] Mealey B.L., Ocampo G.L.: Diabetes mellitus and periodontal disease. Periodontol. 2000, 2007; 44: 127-153.

[2] Naguib G., Al-Mushat H., Desta T., Graves D.T.: Diabetes prolongs the inflammatory response to a bacterial stimulus through cytokine dysregulation. J. Invest. Dermatol., 2004; 123: 87-92.

[3] Duda-SobczakA., Lipski J., Tarnowski M., SurdackaA., ZozulinskaZiolkiewicz D., Wyganowska-Świątkowska M.: Association of skin autofluorescence - a marker of advanced glycation end products accumulation with periodontal inflammation in adults with type 1 diabetes. Pol. Arch. Inter. Med., 2017; 127: 708-718.

[4] Rafatjou R., Razavi Z., Tayebi S., Khalili M., Farhadian M.: Dental health status and hygiene in children and adolescents with type 1 diabetes mellitus. J. Res. Health Sci., 2016; 16: 122-126.

[5] O'Dowd L.K., Durham J., McCracken G.I., Preshaw P.M.: Patients' experiences of the impact of periodontal disease. J. Clin. Periodontol., 2010; 37: 334-339.

[6] Lalla E., Cheng B., Lal S., Kaplan S., Softness B., Greenberg E., Goland R.S., Lamster I.B.: Diabetes-related parameters and periodontal conditions in children. J. Periodontal Res., 2007; 42: 345-349.

[7] Lamster I.B., Lalla E., Borgnakke W.S., Taylor G.W.: The relationship between oral health and diabetes mellitus. J. Am. Dent. Assoc., 2008; 139: 19S-24S.

[8] Loos B.G.: Systemic markers of inflammation in periodontitis. J. Periodontol., 2005; 76: 2106-2115.

[9] Löe H.: The Gingival Index, the Plaque Index and the Retention Index Systems. J. Periodontol., 1967; 38: 610-616.

[10] Novotna M., Podzimek S., Broukal Z., Lencova E., Duskova J.: Periodontal diseases and dental caries in children with type 1 diabetes mellitus. Mediators Inflamm., 2015; 2015: 379626.

[11] Cianciola L.J., Park B.H., Bruck E., Mosovich L., Genco R.J.: Prevalence of periodontal disease in insulin-dependent mellitus (juvenile diabetes). J. Am. Dent. Assoc., 1982; 104: 653-660.

[12] Al-Zahrani M.S., Bissada N.F., Borawskit E.A.: Obesity and periodontal disease in young, middle-aged, and older adults. J. Periodontol., 2003; 74: 610-615. 
[13] Jindal A., Parihar A.S., Sood M., Singh P., Singh N.: Relationship between severity of periodontal disease and control of diabetes (glycated hemoglobin) in patients with type 1 diabetes mellitus. J. Int. Oral Health, 2015; 7: 17-20.

[14] Llambés F., Silvestre F.J., Hernández-Mijares A., Guiha R., Caffesse R.: The effect of periodontal treatment on metabolic control of type 1 diabetes mellitus. Clin. Oral. Investig., 2008; 12 : 337-343.

[15] Pihlstrom B.L., Michalowicz B.S., Johnson N.W.: Periodontal diseases. Lancet, 2005; 366: 1809-1820.

[16] Newman M.G., Takei H., Klokkevold P.R., Carranza F.A.: Carranza's Clinical Periodontology. Saunders Elsevier, 2015: 186-213.

[17] Lobene R.R., Weatherford T., Ross N.M., Lamm R.A., Menaker L.: A modified gingival index for use in clinical trials. Clin. Prev. Dent., 1986; 8: 3-6.

[18] Orbak R., Simsek S., Orbak Z., Kavrut F., Colak M.: The influence of type-1 diabetes mellitus on dentition and oral health in children and adolescents. Yonsei Med. J., 2008; 49: 357-365.

[19] Tarnowski M., Duda-Sobczak A., Zozulińska-Ziółkiewicz D., Wyganowska-Świątkowska M.: Insulinoterapia przy użyciu osobistej pompy insulinowej oraz lepsze wyrównanie glikemii związane z mniejszą akumulacją płytki nazębnej u dorosłych chorych na cukrzycę typu 1. Dental Forum, 2018; 46: 11-16.

[20] Sanz M., Ceriello A., Buysschaert M., Chapple I., Demmer R.T., Graziani F., David Herrera D., Jepsen S., Lione L., Madianos P., et al.: Scientific evidence on the links between periodontal diseases and diabetes: Consensus report and guidelines of the joint workshop on periodontal diseases and diabetes by the International Diabetes Federation and the European Federation of Periodontology. Diabetes Res. Clin. Pract., 2018; 137: 231-241.

[21] Ship J.A.: Diabetes and oral health: An overview. J. Am. Dent. Assoc., 2003; 134: 4S-10S.

[22] Siudikiene J., Maciulskiene V., Dobrovolskiene R., Nedzelskiene I.: Oral hygiene in children with type I diabetes mellitus. Stomatologija, 2005; 7: 24-27.

[23] Lorenzo C., Haffner S.M.: Performance characteristics of the new definition of diabetes: The insulin resistance atherosclerosis study. Diabetes Care, 2010; 33: 335-337.

[24] Dietrich T., Ower P., Tank M., West N.X., Walter C., Needleman I., Hughes F.J., Wadia R., Milward M.R., Hodge P.J., et al.: Periodontal diagnosis in the context of the 2017 classification system of periodontal diseases and conditions - implementation in clinical practice. Br. Dent. J., 2019; 226: 16-22.

[25] Preshaw P.M., Alba A.L., Herrera D., Jepsen S., Konstantinidis A., Makrilakis K., Taylor R.: Periodontitis and diabetes: A two-way relationship. Diabetologia, 2012; 55: 21-31.

[26] D'Aiuto F., Parkar M., Andreou G., Suvan J., Brett P.M., Ready D., Tonetti M.S.: Periodontitis and systemic inflammation: Control of the local infection is associated with a reduction in serum inflammatory markers. J. Dent. Res., 2004; 83: 156-160.

[27] Giuca M.R., Pasini M., Giuca G., Caruso S., Necozione S., Gatto R.: Investigation of periodontal status in type 1 diabetic adolescents. Eur. J. Paediatric Dent., 2015; 16: 319-323.

[28] Bissett S.M., Stone K.M., Rapley T., Preshaw P.M.: An exploratory qualitative interview study about collaboration between medicine and dentistry in relation to diabetes management. BMJ Open, 2013; 3: e002192.

[29] Seethalakshmi C., Jagat Reddy R.C., Asifa N., Prabhu S.: Correlation of salivary $\mathrm{pH}$, incidence of dental caries and periodontal status in diabetes mellitus patients: A cross-sectional study. J. Clin. Diagn. Res. 2016; 10: ZC12-ZC14.

[30] Sadeghi R., Teleghani F., Mohammadi S., Zohri Z.: The effect of diabetes mellitus type I on periodontal and dental status. J. Clin. Diagn. Res., 2017; 11: ZC14-ZC17.

[31] Tuleutaeva S., Ashirbekova Z., Manapova D., Almurat S., Kharchenko V.: Periodontal disease in children with diabetes mellitus type 1. Georgian Med. News, 2014; 235: 25-29.

[32] Chávarry N.G., Vettore M.V., Sansone C., Sheiham A.: The relationship between diabetes mellitus and destructive periodontal disease: A meta-analysis. Oral Health Prev. Dent., 2009; 7: 107127.

[33] Acunzo R., Limiroli E., Pagni G., Dudaite A., Consonni D., Rasperini G.: Gingival margin stability after mucogingival plastic surgery. The effect of manual versus powered toothbrushing: A randomized clinical trial. J. Periodontol., 2016; 87: 1186-1194.

[34] Pischon N., Heng N., Bernimoulin J.P., Kleber B.M., Willich S.N., Pischon T.: Obesity, inflammation, and periodontal disease. J. Dent. Res., 2007; 86: 400-409.

[35] Aldridge J.P., Lester V., Watts T.L., Collins A., Viberti G., Wilson R.F.: Single-blind studies of the effects of improved periodontal health on metabolic control in type 1 diabetes mellitus. J. Clin. Periodontol., 1995; 22: 271-275.

[36] Xavier A.C., Silva I.N., Costa F.deO., Corrêa D.S.: Periodontal status in children and adolescents with type 1 diabetes mellitus. Arq. Bras. Endocrinol. Metabol., 2009; 53: 348-354.

[37] Silva A.M., Vargas A.M, Ferreira E.F., de Abreu M.H.: Periodontitis in individuals with diabetes treated in the public health system of Belo Horizonte. Brazil. Rev. Bras. Epidemiol., 2010; 13, 118-125.

[38] Al-Shammari K.F., Al-Ansari J.M., Moussa N.M., Ben-Nakhi A., Al-Arouj M., Wang H.L.: Association of periodontal disease severity with diabetes duration and diabetic complications in patients with type 1 diabetes mellitus. J. Int. Acad. Periodontol., 2006; 8: 109-114.

[39] World Health Organization (WHO). Use of glycated haemoglobin $(\mathrm{HbA} 1 \mathrm{c})$ in the diagnosis of diabetes mellitus, 2011 